J. Dairy Sci. 92:25-34

doi:10.3168/jds.2008-1081

(c) American Dairy Science Association, 2009.

\title{
Involvement of Acetobacter orientalis in the production of lactobionic acid in Caucasian yogurt ("Caspian Sea yogurt") in Japan
}

\author{
T. Kiryu, ${ }^{* 1}$ T. Kiso, ${ }^{*}$ H. Nakano, ${ }^{\star}$ K. Ooe, $†$ T. Kimura, $†$ and H. Murakami* \\ *Osaka Municipal Technical Research Institute, 6-50, Morinomiya 1-chome, Joto-ku, Osaka 536-8553, Japan \\ †Central Research Laboratories, Untika Co. Ltd., 23, Ujikozakura, Uji, Kyoto 611-0021, Japan
}

\begin{abstract}
Lactobionic acid was first found in a Caucasian fermented milk product popularly known as "Caspian Sea yogurt" in Japan. The presence of lactobionic acid in the fermented milk was indicated by the results of both high-performance anion-exchange chromatographic analysis with pulsed amperometric detection and mass spectrometric analysis. Thereafter, the acid was purified from the yogurt and analyzed by nuclear magnetic resonance. A substantial amount of lactobionic acid was found to be accumulated in the upper layer of the yogurt, especially within $10 \mathrm{~mm}$ from the surface. A total of $45 \mathrm{mg}$ of lactobionic acid per $100 \mathrm{~g}$ of the upper yogurt layer was collected after $4 \mathrm{~d}$ of fermentation. The annual intake of lactobionic acid in individuals consuming $100 \mathrm{~g}$ of the yogurt every day would be 0.5 to $1.0 \mathrm{~g}$. A lactose-oxidizing bacterium was isolated from the fermented milk and was identified as Acetobacter orientalis. Washed A. orientalis cells oxidized monosaccharides such as D-glucose at considerable rates, although their activities for substrates such as lactose, maltose, and cellobiose were much lower. When A. orientalis cells were cultivated in cow's milk, they exhibited lactose-oxidizing activity, suggesting that this bacterium was the main organism involved in the production of lactobionic acid in the yogurt.
\end{abstract}

Key words: lactobionic acid, Acetobacter orientalis, Caspian Sea yogurt

\section{INTRODUCTION}

Lactobionic acid [ $\beta$-D-galactopyranosyl- $(1 \rightarrow 4)$-Dgluconic acid, LacA] is a component of the preservative solution used during organ transplantation (Wahlberg et al., 1987; Sumimoto et al., 1992) and is also used as an ingredient in the antibiotic erythromycin lactobionate (Neaverson, 1976). Lactobionic acid is thought to have several additional functions, such as in the for-

Received February 5, 2008.

Accepted September 7, 2008.

${ }^{1}$ Corresponding author: kiryu@omtri.city.osaka.jp mation of soluble salts with calcium to increase their intestinal adsorption (Brommage et al., 1993; Nakano et al., 2006). Thus, LacA might have potential for use in calcium supplements. Bacteria (Satory et al., 1997; Murakami et al., 2002, 2006) and fungi (Ludwig et al., 2004; Hua et al., 2007; Kiryu et al., 2008) with lactose-oxidizing activity have been studied as a means of producing LacA from lactose. The microorganisms used in these studies, however, are not suitable for food production. Therefore, it is necessary to find a bacterium used in food production, such as Acetobacter sp., for LacA production. Acetobacter sp. is one of the most important bacteria used in food production. It is used in the production of vinegar and the Caucasian yogurt studied here. The occurrence of LacA in foods and beverages also helps in the practical application of LacA, because it indicates that people have unconsciously consumed LacA for a long time. To our knowledge, the natural occurrence of LacA has not been demonstrated previously.

Caucasian yogurt, also known as "Caspian Sea yogurt" in Japan, was traditionally produced in the Caucasus region in the western part of Eurasia, and is believed to have been introduced into Japan from the village of Java, Georgia, in 1986 (Akatani and Ishida, 2002; Ishida et al., 2005). This yogurt has a lower acidity and greater viscosity than typical yogurts. In an early study, 3 bacteria, Lactococcus lactis ssp. cremoris, Leuconostoc sp., and Gluconobacter sp., were isolated from Caucasian yogurt (Akatani and Ishida, 2002). However, reexamination revealed that $L$. lactis ssp. cremoris and Acetobacter orientalis were the main bacteria involved in the production of the yogurt (Ishida et al., 2005). This yogurt is easily fermented after adding $1 / 10$ to $1 / 20 \mathrm{vol}$ of the seed yogurt to milk at room temperature, because the yogurt is fermented at a lower temperature (approximately 25 to $30^{\circ} \mathrm{C}$ ) than typical yogurts. Because of this easy preparation, the yogurt has gained ground among Japanese people by word of mouth, and has become known as Caspian Sea yogurt. Fujicco (Hyogo, Japan), a major Japanese food company, has been selling seed powder of the yogurt (a mixture of dried cells of L. lactis ssp. cremoris and A. orientalis) since 2002, 
and the yogurt has become widely available in Japan. According to the Web site of the company (http:// www.caspia.jp/), 1 million packages of powdered seed have been sold thus far. The yogurts derived from these powdered seed cells are fermented in Japanese homes.

\section{MATERIALS AND METHODS}

\section{Materials}

Commercial cow's milk was used (butterfat content, $3.5 \%$ ). A powdered culture of Caucasian yogurt was obtained from Fujicco. Authentic LacA was purchased from Wako Pure Chemical Industries (Osaka, Japan). Maltobionic acid [ $\alpha$-D-glucopyranosyl- $(1 \rightarrow 4)$-D-gluconic acid] and cellobionic acid [ $\beta$-D-glucopyranosyl-( $1 \rightarrow 4)$-Dgluconic acid] were prepared by oxidizing maltose and cellobiose, respectively, by using a carbohydrate:acceptor oxidoreductase from Paraconiothyrium sp., as described previously (Kiryu et al., 2008).

\section{Preparation of the Caucasian Yogurt}

Powdered culture $(3.0 \mathrm{~g})$ was mixed with fresh cow's milk $(30 \mathrm{~mL})$ and was incubated at $27^{\circ} \mathrm{C}$ for $24 \mathrm{~h}$ under static conditions to prepare a seed culture. The starter culture was prepared as follows: fresh cow's milk was mixed with $1 / 10$ vol of the seed culture and then incubated at $27^{\circ} \mathrm{C}$ for $24 \mathrm{~h}$. This starter culture was stored at $4^{\circ} \mathrm{C}$ until seeding. The yogurt was fermented by adding the starter culture under the same conditions used to prepare the starter culture.

\section{High-Performance Anion-Exchange Chromatography with Pulsed Amperometric Detection Analysis}

After removal of the protein and other insoluble materials from the fermented milk samples, the samples were analyzed for the presence of LacA by high-performance anion-exchange chromatography with pulsed amperometric detection (HPAEC-PAD; Dionex Corporation, Sunnyvale, CA). To remove protein from the yogurt samples, water (same volume) and 1.0 $\mathrm{M}$ acetate (one-fifth the volume; special grade) were added to the yogurt sample and mixed vigorously. The precipitates thus formed were removed by centrifugation at 7,000 $\times g$ for $10 \mathrm{~min}$ at $18^{\circ} \mathrm{C}$. The supernatant was then mixed with ethanol (one-half the volume) and immediately centrifuged again under the same conditions to remove the precipitate. The supernatant was subjected to HPAEC-PAD. Analysis was performed under the following conditions: system, Dionex DX-500; detector, Dionex Model PAD II pulsed amperometric detector; column, Dionex Carbopac PA-1 $(40 \times 250 \mathrm{~mm})$; elution, linear gradient from 150 to $300 \mathrm{~m} M$ sodium acetate in $100 \mathrm{~m} M \mathrm{NaOH}$; flow rate, $1.0 \mathrm{~mL} / \mathrm{min}$; temperature, $35^{\circ} \mathrm{C}$.

\section{Isolation of LacA from Caucasian Yogurt}

To prepare the yogurt, $50 \mathrm{~g}$ of the starter culture was added to cow's milk (500 $\mathrm{mL}$ in a 3 -L flask) and incubated for $5 \mathrm{~d}$ at $27^{\circ} \mathrm{C}$. The fermented milk was centrifuged at $5,000 \times g$ for $30 \mathrm{~min}$ at $10^{\circ} \mathrm{C}$, and the precipitate was removed. Ethanol (one-half the volume; $250 \mathrm{~mL}$ ) was added to the supernatant $(500 \mathrm{~mL})$, and the mixture was centrifuged again at $5,000 \times g$ for 30 min at $10^{\circ} \mathrm{C}$. The supernatant solution was then applied to an anion-exchange column (Diaion PA 406S column, diameter $20 \times 30 \mathrm{~mm}$; Mitsubishi Chemical Corporation, Tokyo, Japan) equilibrated with water. The fractions were eluted with a linear gradient of 0 to 0.01 $N \mathrm{HCl}$ at $20^{\circ} \mathrm{C}$ (flow rate, $1.0 \mathrm{~mL} / \mathrm{min}$ ) and the fractions were analyzed by HPAEC-PAD analysis. Excess methanol was added to the fractions containing LacA and evaporated to remove the $\mathrm{HCl}$. Further purification was carried out by thin-layer chromatography (TLC) under the following conditions: TLC plates, Kaisel Gel 60 (Merck, Darmstadt, Germany); solvent system, ethyl acetate:acetic acid:water (3:1:1, by vol). The plate was heated to $150^{\circ} \mathrm{C}$ and sprayed with $50 \%$ (wt/wt) $\mathrm{H}_{2} \mathrm{SO}_{4}$ in methanol, revealing spots of sugars. The silica gel on the TLC plate (without spraying and heating), having approximately the same mobility as that of LacA, was recovered with a spatula and suspended in water (1.0 $\mathrm{mL}$ ). After centrifugation, the supernatant containing the extracted LacA was collected and evaporated.

\section{Mass Spectrometry Analysis}

The LacA sample isolated from the Caucasian yogurt was diluted with $60 \%$ acetonitrile and analyzed with an API 2000 mass spectrometer (Applied Biosystems, Foster City, CA) as follows: ionization, electron-spray ionization; ion spray voltage, $5,000 \mathrm{~V}$; detection, negative ion mode. The mass of LacA $\left[(m / z)^{-}=357\right]$ was determined from the mass of pseudomolecular ions ([M $\left.-\mathrm{H}]^{-}\right)$. The signal derived from LacA $\left[(m / z)^{-}=357\right]$ was fragmented by $25 \mathrm{~V}$ of collision energy.

\section{Nuclear Magnetic Resonance}

The ${ }^{1} \mathrm{H}$-nuclear magnetic resonance (NMR; 300 $\mathrm{MHz})$ and ${ }^{13} \mathrm{C}-\mathrm{NMR}(75 \mathrm{MHz})$ spectra were recorded for a solution of $1 \%$ sample in deuterium oxide $\left(\mathrm{D}_{2} \mathrm{O}\right)$ by using a Jeol AL-FTNMR spectrometer (Jeol Ltd., Tokyo, Japan). 3-(Trimethylsilyl)-1-propanesulfonic acid sodium salt was used as the internal standard. 


\section{Analysis of LacA Concentrations in Various Layers of the Caucasian Yogurt}

The starter culture $(5 \mathrm{~g})$ was used to inoculate $45 \mathrm{~mL}$ of fresh cow's milk in a plastic tube $(50 \mathrm{~mL}$; diameter, $30 \mathrm{~mm}$ ) with a silicone cap. After $5 \mathrm{~d}$ of static cultivation at $27^{\circ} \mathrm{C}$ under aerobic conditions, the fermented milk was frozen at $-20^{\circ} \mathrm{C}$ and cut into disks of $10-\mathrm{mm}$ layers. These layers of fermented milk were then defrosted, deproteinized, and subjected to HPAEC-PAD analysis.

\section{Isolation of LacA-Producing Bacterium from the Caucasian Yogurt}

Yogurt culture (10 mg) was used to inoculate a yeast extract-polypepton-glucose-lactose (YPGL; $5.0 \mathrm{~mL}$, $\mathrm{pH}$ 7.0) liquid medium consisting of $0.5 \%$ dried yeast extract (D-3, Nihon Pharmaceutical, Tokyo, Japan), $0.5 \%$ polypepton (Nihon Pharmaceutical), $0.5 \%$ lactose, $0.5 \%$ D-glucose, $0.1 \% \mathrm{MgSO}_{4}$. The culture medium was shaken (240 oscillations/min) to selectively proliferate aerobic bacteria. After $24 \mathrm{~h}$ of culture at $27^{\circ} \mathrm{C}, 0.8 \mu \mathrm{L}$ of the culture liquid was streaked onto YPGL plates (1.5\% agar) and the plates were incubated for a further $24 \mathrm{~h}$ at $27^{\circ} \mathrm{C}$. The isolates were then cultured in the YPGL liquid medium $(5.0 \mathrm{~mL})$ at $27^{\circ} \mathrm{C}$ for $48 \mathrm{~h}$ with shaking (240 oscillation/min). The cells were harvested by centrifugation $\left(5,000 \times g, 10 \mathrm{~min}, 18^{\circ} \mathrm{C}\right)$ and washed with $0.85 \% \mathrm{NaCl}$. The washed cells were incubated with $2 \%$ lactose solution $(1.0 \mathrm{~mL})$ containing $\mathrm{CaCO}_{3}$ (2.8 mg, $1 / 2$ equimolar amount of lactose) at $27^{\circ} \mathrm{C}$ for $48 \mathrm{~h}$ with shaking (240 oscillations/min). After removal of the cells, the reaction mixture was analyzed by TLC to select the LacA-producing bacteria.

\section{Conversion of Several Saccharides by Washed A. orientalis Cells}

Acetobacter orientalis KYG22 was cultivated in YPGL liquid medium $(5.0 \mathrm{~mL})$ at $27^{\circ} \mathrm{C}$ with shaking (240 oscillations/min). The cells in $1.0 \mathrm{~mL}$ of culture medium were collected by centrifugation, washed with $0.85 \% \mathrm{NaCl}$, suspended in $100 \mu \mathrm{L}$ of $0.85 \% \mathrm{NaCl}$, and incubated with $900 \mu \mathrm{L}$ of the substrate solution, consisting of $10 \mathrm{~m} M$ of each saccharide (D-glucose, D-galactose, D-mannose, D-xylose, L-arabinose, maltose, lactose, cellobiose) and $100 \mathrm{mM}$ of acetate buffer $(\mathrm{pH} 5.5)$ at $27^{\circ} \mathrm{C}$ with reciprocal shaking (240 oscillations/min). After $3 \mathrm{~h}$, the reaction mixtures were boiled for $5 \mathrm{~min}$ and the oxidized products were analyzed by HPAEC-PAD. The oxidized disaccharides and monosaccharides were evaluated by using LacA and D-glucuronic acid as the standard, respectively.
Time Course of LacA Production by A. orientalis Cells

Acetobacter orientalis strain KYG22 was cultivated in $50 \mathrm{~mL}$ of YPGL liquid medium at $27^{\circ} \mathrm{C}$ for $48 \mathrm{~h}$ with shaking (120 oscillations/min) in a $500-\mathrm{mL}$ shaking flask, and the cells were collected from $10 \mathrm{~mL}$ of culture broth by centrifugation at 7,000 $\times g$ for $30 \mathrm{~min}$ at $18^{\circ} \mathrm{C}$. After washing with $0.85 \% \mathrm{NaCl}$, the cells were suspended in $1.0 \mathrm{~mL}$ of reaction mixture containing $2 \%$ lactose and $2.8 \mathrm{mg}$ of $\mathrm{CaCO}_{3}(1 / 2$ equimolar amount of lactose), then incubated at $35^{\circ} \mathrm{C}$ with shaking $(240$ oscillations/min) in test tubes. The cells were removed by centrifugation, and LacA production was measured by HPAEC-PAD.

\section{Estimation of Daily and Annual Intakes of LacA}

A starter culture for the Caucasian yogurt (100 g) was mixed with $600 \mathrm{~mL}$ of commercial fresh milk and fermented by using a household yogurt maker (Yogurutia Model YM-1200; Tanica Electric, Gifu, Japan) at $27^{\circ} \mathrm{C}$ for $12 \mathrm{~h}$. The yogurt was stored at $4^{\circ} \mathrm{C}$ for 12 $\mathrm{h}$, after which $100 \mathrm{~g}$ of the upper part of the sample was subjected to HPAEC-PAD analysis, as described above. In addition, $100 \mathrm{~g}$ of the yogurt was sampled every $24 \mathrm{~h}(36,60,84,108,132 \mathrm{~h})$ for LacA measurement. Based on the assumption that $100 \mathrm{~g}$ of the yogurt would be eaten every day, the daily and annual intakes of LacA were estimated from the total amounts of LacA in the sampled yogurts (12 to $132 \mathrm{~h}$ ), defined as $6 \mathrm{~d}$ of intake.

\section{Lactose-Oxidizing Activity Assay Using a D-Gluconic Acid Measurement Kit}

The activity of the cells was calculated based on LacA production. Lactobionic acid was measured as Dgluconic acid after acid hydrolysis as follows. A cell suspension or sonicated cell solution $(250 \mu \mathrm{L})$ was mixed with a mixture $(250 \mu \mathrm{L})$ containing $400 \mathrm{~m} M$ lactose and $200 \mathrm{~m} M$ acetate buffer ( $\mathrm{pH} 5.5$ ), then incubated at $40^{\circ} \mathrm{C}$ for $10 \mathrm{~min}$. Fifty microliters of $1.0 \mathrm{~N} \mathrm{NaOH}$ was added to the reaction mixture to stop the reaction. The mixture was neutralized by adding $50 \mu \mathrm{L}$ of $1.0 \mathrm{~N}$ $\mathrm{HCl}$. The reaction mixture was boiled with $500 \mu \mathrm{L}$ of $2.0 \mathrm{~N} \mathrm{HCl}$ for $40 \mathrm{~min}$ to hydrolyze LacA to D-gluconic acid and D-galactose. After adding $2.0 \mathrm{~N} \mathrm{NaOH}(500$ $\mu \mathrm{L}$ ), the amount of D-gluconic acid was measured with a D-gluconic acid measurement kit (F-kit, D-Gluconic acid/D-Glucono- $\delta$-lactone; Boehringer Mannheim, Mannheim, Germany). One unit of the cells was defined as the amount of cells that produced $1 \mu \mathrm{mol}$ of LacA per minute. 

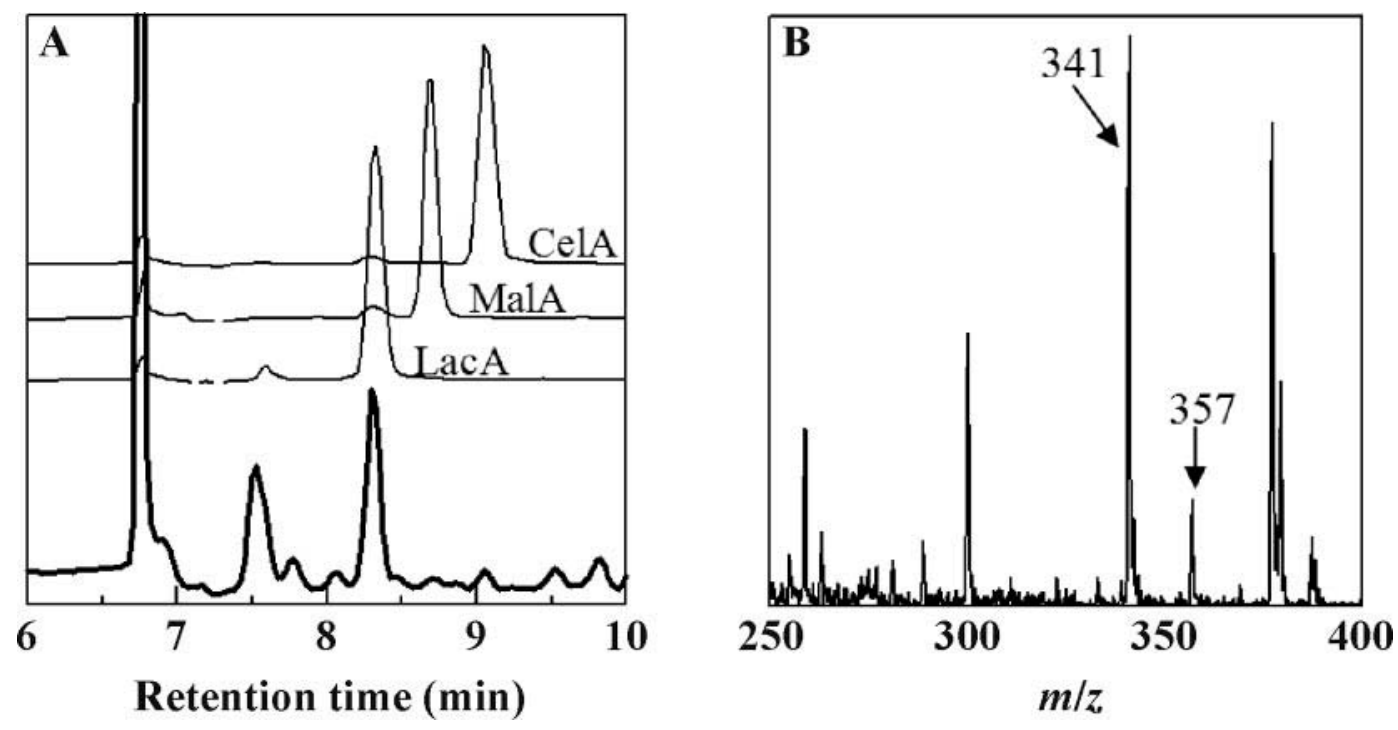

Figure 1. Occurrence of lactobionic acid (LacA) in the Caucasian yogurt. (A) The Caucasian yogurt was analyzed by high-performance anion-exchange chromatography with pulsed amperometric detection (bold line). Lactobionic acid, maltobionic acid (MalA), and cellobionic acid (CelA) standards were also analyzed. (B) Mass spectrometry analysis of Caucasian yogurt. The signals at $(\mathrm{m} / z)^{-}=357$ and $(\mathrm{m} / z)^{-}=341$ corresponded to those of LacA and lactose, respectively.

\section{Utilization of LacA as a Carbon Source by A. orientalis}

Acetobacter orientalis strain KYG22 was cultured in YPGL liquid medium $(5.0 \mathrm{~mL})$ at $27^{\circ} \mathrm{C}$ for $48 \mathrm{~h}$. Ten milliliters of the culture broth was diluted $1.0 \times 10^{4}$ fold, and the diluted sample $(200 \mu \mathrm{L})$ was plated on mineral medium plates ( $\mathrm{pH} 5.5$ to 6.0 ) consisting of $\mathrm{NaCl}(0.2 \%), \mathrm{NH}_{3} \mathrm{NO}_{3}(0.2 \%), \mathrm{KH}_{2} \mathrm{PO}_{4}(0.1 \%), \mathrm{K}_{2} \mathrm{H}-$ $\mathrm{PO}_{4}(0.1 \%)$, sugar (D-glucose or LacA, 1\%), and agar $(1.5 \%)$. The plates were incubated for $72 \mathrm{~h}$ at $27^{\circ} \mathrm{C}$, and growth of the bacterium was observed.

\section{Effects of $\mathrm{pH}$ and Temperature on A. orientalis Cells}

Acetobacter orientalis strain KYG22 was cultured in YPGL liquid medium $(1.0 \mathrm{~mL})$ at $27^{\circ} \mathrm{C}$ with shaking (240 oscillation/min) for $3 \mathrm{~d}$. The cells were collected by centrifugation $\left(5,000 \times \mathrm{g}, 10 \mathrm{~min}\right.$ at $\left.18^{\circ} \mathrm{C}\right)$ and suspended in $250 \mu \mathrm{L}$ of $0.85 \% \mathrm{NaCl}$. To determine the optimal $\mathrm{pH}$, the activity of the cell suspension was measured with a D-gluconic acid measurement kit. The $\mathrm{pH}$ of the reaction mixtures was adjusted with $100 \mathrm{mM}$ sodium acetate- $\mathrm{HCl}$ buffer (pH 2.0 to 4.0), acetate buffer ( $\mathrm{pH} 4.0$ to 5.5), phosphate buffer ( $\mathrm{pH} 7.0$ to 8.0), and glycine-HCl buffer ( $\mathrm{pH} 9.0$ to 11.0). To measure $\mathrm{pH}$ stability, the cell suspension $(250 \mu \mathrm{L})$ was mixed with $50 \mu \mathrm{L}$ of $250 \mathrm{~m} M$ sodium acetate-HCl buffer ( $\mathrm{pH}$ 2.0 to 4.0 ), acetate buffer ( $\mathrm{pH} 4.0$ to 5.5), phosphate buffer ( $\mathrm{pH} 7.0$ to 8.0 ), and glycine-HCl buffer ( $\mathrm{pH} 9.0$ to 11.0 ), and was incubated at $40^{\circ} \mathrm{C}$ for $24 \mathrm{~h}$. The cell suspension was mixed with the reaction mixture (300
$\mathrm{mL}$ ) containing $400 \mathrm{~m} M$ lactose and $400 \mathrm{~m} M$ acetate buffer ( $\mathrm{pH} 5.5$ ), and the activity was measured. To determine the optimal temperature, activities of the cells were measured at 5 to $80^{\circ} \mathrm{C}$. To measure thermal stability, cells in $100 \mathrm{mM}$ acetate buffer ( $\mathrm{pH} 5.5$ ) were treated at 0 to $80^{\circ} \mathrm{C}$ for $30 \mathrm{~min}$. The activity of the treated cells was measured by adding them to $1 / 5 \mathrm{vol}$ of $1.0 \mathrm{M}$ lactose.

\section{Preparation of Soluble and Membrane-Bound Fractions of $A$. orientalis Cells}

To investigate whether the lactose-oxidizing enzyme of $A$. orientalis was membrane bound or soluble, $A$. orientalis KYG22 was cultured for $2 \mathrm{~d}$, collected by centrifugation $\left(5,000 \times g, 10 \mathrm{~min}\right.$ at $\left.5^{\circ} \mathrm{C}\right)$, washed, suspended in $100 \mathrm{mM}$ acetate buffer ( $\mathrm{pH} 5.5)$, and sonicated on ice by using an Ultrasonic Homogenizer 5202 with a CN 1005 horn tip (Otake Seisakusho, Tokyo, Japan). After $10 \mathrm{~min}$ of sonication, the homogenate sample was centrifuged $\left(5,000 \times g, 10 \mathrm{~min}\right.$ at $\left.5^{\circ} \mathrm{C}\right)$. The supernatant and the precipitates were used as the soluble and membrane fractions, respectively.

\section{RESULTS}

\section{Detection and Identification of LacA in the Caucasian Yogurt}

We suspected, based on the fact that 5.0 to $5.5 \%$ of milk is lactose, that LacA would be produced in fermented milk. We therefore analyzed 25 fermented milk 
samples and eventually found a peak that appeared at the same retention time as that of the LacA standard in a Caucasian yogurt, popularly known as Caspian Sea yogurt in Japan (Figure 1A). When a LacA standard solution was added to the deproteinized yogurt sample, the peak was enlarged. The retention times of maltobionic acid and cellobionic acid were different from that of LacA. The peak was absent from the other yogurts tested. As shown in Figure 1B, mass spectrometry analysis also indicated the existence of LacA $\left[(m / z)^{-}=\right.$ $357]$ in the yogurt. The compound corresponding to the peak (compound A) was purified from the yogurt by using an anion-exchanger and TLC for analysis with a mass spectrometer. The signal of purified compound A was the same as that of LacA $\left[(m / z)^{-}=357\right]$. When the signal $\left[(\mathrm{m} / z)^{-}=357\right]$ was trapped and fragmented, the fragmentation pattern was the same as that of the LacA standard (Figure 2). Compound A was also isolated from the yogurt and further identified as LacA by ${ }^{1} \mathrm{H}$ - and ${ }^{13} \mathrm{C}-\mathrm{NMR}$. The carbon and proton signals of purified compound A coincided with those of the LacA standard (data not shown; Murakami et al., 2002).

\section{Production of LacA in Various Layers of the Caucasian Yogurt}

The oxidation of lactose is considered to proceed under aerobic conditions in fermented milk. Therefore, LacA production in various layers of the yogurt was

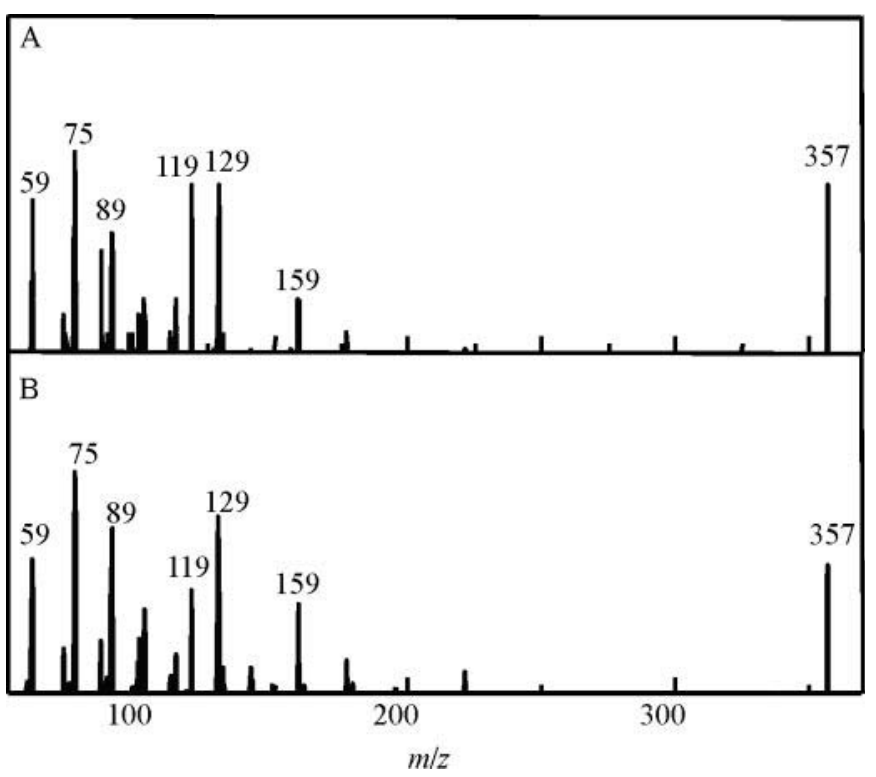

Figure 2. Mass/mass analysis of purified lactobionic acid (LacA). A sample of LacA purified from Caucasian yogurt was subjected to mass spectrometry analysis. The LacA signal $\left[(m / z)^{-}=357\right]$ was trapped and fragmented (A). The LacA standard was also fragmented under the same conditions (B). The $m / z$ values of the major fragments are indicated above. measured (Figure 3). To measure the LacA concentration in each layer, the yogurt was prepared in plastic tubes and frozen. After the frozen yogurt was removed from the tube, it was cut into 4 layers as shown in Figure 3. Each layer was deproteinized, and the LacA concentration was measured by HPAEC-PAD. The first fraction (surface layer, 0 to $10 \mathrm{~mm}$ ) contained the largest concentration of LacA (more than $10 \mathrm{mg} / 100 \mathrm{~g}$ of yogurt). The deeper layers contained noticeably less LacA.

\section{Time Course of Accumulation of LacA in Caucasian Yogurt and Estimation of Annual Intake of LacA}

The amount of LacA in the upper layer was greater than the amounts in the lower layers (Figure 3). Thus, to investigate LacA production in the upper layer of the yogurt, the yogurt was prepared from a thin (50$\mathrm{mm}$ ) layer of cow's milk and the amount of LacA was measured after different culture periods (Figure 4). The starter culture $(1.0 \mathrm{~g})$ and fresh cow's milk $(10 \mathrm{~mL})$ were mixed in a 100-mL flask (thickness, $50 \mathrm{~mm}$ ) and incubated at $27^{\circ} \mathrm{C}$. The $\mathrm{pH}$ of the yogurt was changed to 4.6 for $6 \mathrm{~h}$ and 4.2 for $10 \mathrm{~h}$. The milk began to thicken after $8 \mathrm{~h}$, and the surface of the yogurt turned a light reddish-brown color, probably because of the growth of the aerobic bacterium A. orientalis in the yogurt. During fermentation, the amount of LacA gradually increased, and $45 \mathrm{mg}$ of LacA accumulated in $100 \mathrm{~g}$ of the upper layer of the yogurt after $4 \mathrm{~d}$.

Next, the daily and annual intakes of LacA were estimated, assuming that the yogurt was eaten every day. The yogurt was prepared by using the Yogu-rutia Model YM-1200, a commercial fermented milk maker (n $=3)$. Starter culture $(100 \mathrm{~g})$ was inoculated into fresh milk $(600 \mathrm{~mL})$ and incubated at $27^{\circ} \mathrm{C}$ for $12 \mathrm{~h}$, and the prepared yogurt was stored at $4^{\circ} \mathrm{C}$. The upper part of the yogurt (100 g) was collected at various times, and the amount of LacA was measured by HPAEC-PAD (Figure 5). The isolated yogurt samples contained 1.4 $\pm 0.2 \mathrm{mg}(12 \mathrm{~h}), 2.3 \pm 0.4 \mathrm{mg}(36 \mathrm{~h}), 2.8 \pm 0.6 \mathrm{mg}(60$ h), $2.5 \pm 0.7 \mathrm{mg}(84 \mathrm{~h}), 1.7 \pm 0.4 \mathrm{mg}(108 \mathrm{~h}), 1.8 \pm 0.5$ $\mathrm{mg}(132 \mathrm{~h})$, and $2.1 \mathrm{mg}$ (average) of LacA in $100 \mathrm{~g}$ of yogurt. Assuming that $100 \mathrm{~g}$ of yogurt was consumed each day, the intake of LacA over a 6-d period (12 to $132 \mathrm{~h}$ ) would be $12.6 \mathrm{mg}$, as shown in Figure 5. Thus, the annual intake of LacA was calculated to be approximately $760 \mathrm{mg}$.

\section{Identification of a Lactose-Oxidizing Bacterium, A. orientalis, and Its Sugar-Oxidizing Properties in Caucasian Yogurt}

The LacA-producing bacterial strain KYG22 was isolated from the fermented milk. Strain KYG22 is a 

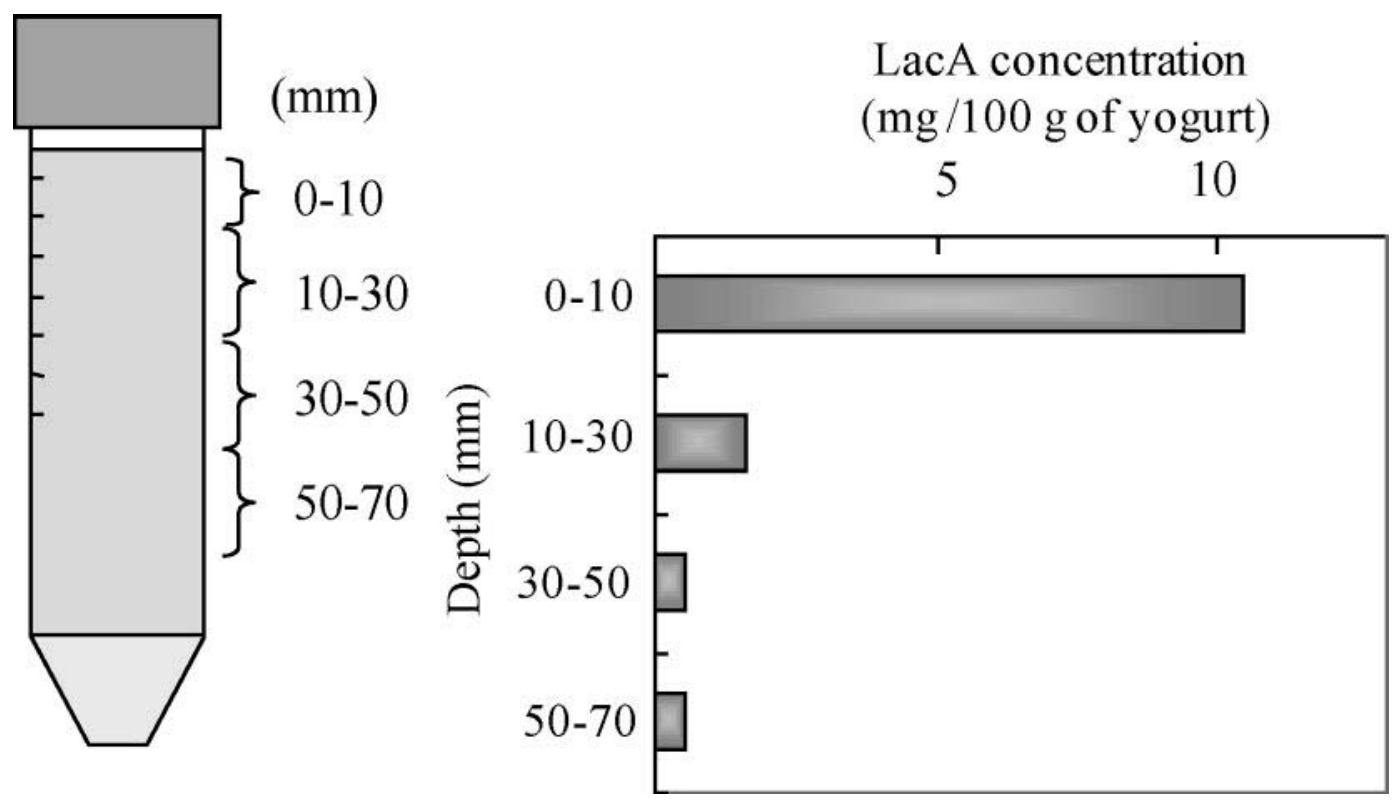

Figure 3. Production of lactobionic acid (LacA) in various layers of Caucasian yogurt. After fermentation, the yogurt was frozen and cut into 4 layers, as indicated in the figure. Each layer was treated as described in the Materials and Methods section, and the LacA concentration was measured by high-performance anion-exchange chromatography with pulsed amperometric detection.

gram-negative bacillus and was identified as A. orientalis based on its $16 \mathrm{~S}$ ribosomal DNA and phenotypic properties as analyzed by TechnoSuruga Laboratory (Shizuoka, Japan; data not shown) NCIMB Japan. The properties of lactose oxidation by $A$. orientalis were then investigated. The bacterium was cultivated by using fresh cow's milk $(2.0 \mathrm{~mL})$ and YPGL liquid medium $(2.0 \mathrm{~mL})$ for $24 \mathrm{~h}$ at $27^{\circ} \mathrm{C}$ with and without shaking. The fermented milk did not thicken, probably because of insufficient lactic acid production. After $2 \mathrm{~d}$ of cultivation, the cells were collected and the growth of the cells $\left(\mathrm{A}_{660}\right.$ value $)$ in YPGL medium with and without shaking was evaluated: these values were 1.2 and 0.2 , respectively. The washed cells reacted with $1.0 \mathrm{~mL}$ of $2 \%$ lactose in $50 \mathrm{mM}$ of acetate buffer ( $\mathrm{pH} 5.5$ ) for $7 \mathrm{~h}$ at $27^{\circ} \mathrm{C}$ with shaking (240 oscillation/min). Production of LacA was evaluated by TLC (Figure 6). The cells cultured in milk oxidized lactose at a rate very similar to that of cells in YPGL medium. The production of LacA with shaking, however, was much greater than that without shaking. The time course of lactose oxidation in washed $A$. orientalis cells is shown in Figure 7. When washed cells of the strain were incubated with $2 \%$ lactose with shaking, $0.72 \%$ of LacA was produced after $72 \mathrm{~h}$ of incubation.

\section{Characterization of the Sugar-Oxidizing Activities of A. orientalis Cells}

Acetobacter orientalis was cultivated on mineral medium plates containing D-glucose or LacA as the sole carbon source. The bacterium grew on plates containing D-glucose but produced no colonies on plates containing LacA. The effects of $\mathrm{pH}$ and temperature on the oxidizing activities of washed $A$. orientalis cells were investigated. The optimal $\mathrm{pH}$ for the oxidizing activity of the cells was 5.5, and the cells oxidized lactose most efficiently at $48^{\circ} \mathrm{C}$. The $\mathrm{pH}$ stability range was

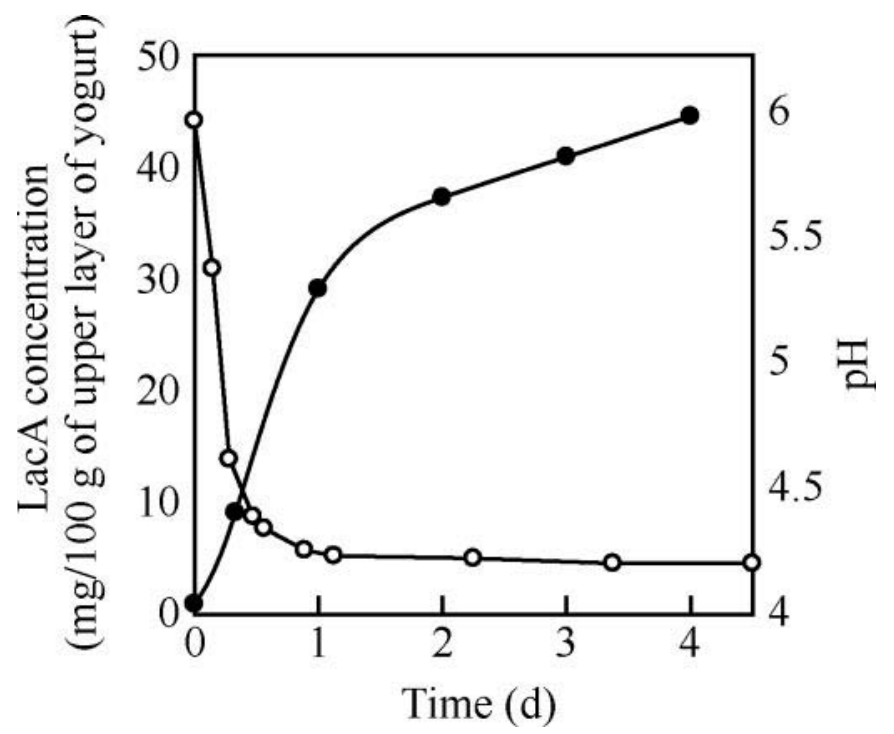

Figure 4. Time course of lactobionic acid (LacA) accumulation in the upper layer of the Caucasian yogurt. The yogurt $(10 \mathrm{~mL})$ was prepared in a $100-\mathrm{mL}$ flask (thick, $0.5 \mathrm{~cm}$ ) at $27^{\circ} \mathrm{C}$. Lactobionic acid (closed circle) and $\mathrm{pH}$ (open circle) were measured after various periods of fermentation. 


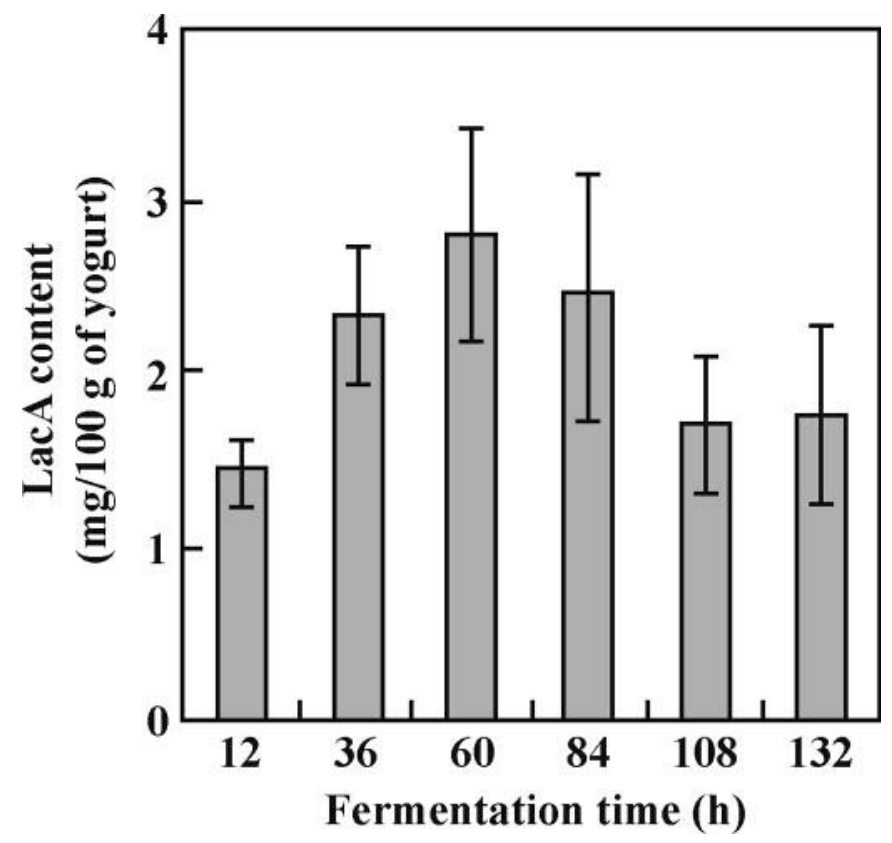

Figure 5. Estimation of daily intake of lactobionic acid (LacA). The Caucasian yogurt (approximately $700 \mathrm{~mL}$ ) was prepared with a yogurt maker. After $12 \mathrm{~h}$ of fermentation at $27^{\circ} \mathrm{C}$, the yogurt was stored at $4^{\circ} \mathrm{C}$. One hundred grams of yogurt was sampled at $12 \mathrm{~h}$ and every $24 \mathrm{~h}$ thereafter $(36,60,84,108,132 \mathrm{~h})$ to measure the LacA concentration by high-performance anion-exchange chromatography with pulsed amperometric detection. Results are means \pm standard deviation $(\mathrm{n}=3)$.

6.0 to 7.5 , and thermostability was less than $55^{\circ} \mathrm{C}$. The specificity of $A$. orientalis cells with respect to several sugars is shown in Figure 8. The bacterium efficiently oxidized D-glucose and several other monosaccharides; however, it exhibited low activities for lactose, maltose, and cellobiose (relative activities 0.04, 0.05, and 0.07\%, respectively). The bacterium was sonicated, and the disrupted cells were separated into soluble and membrane fractions. Most of the lactose-oxidizing activity was detected in the membrane fraction, indicating that the enzyme involved in the oxidation of lactose was probably a membrane-bound enzyme.

\section{DISCUSSION}

Lactose oxidation by $A$. orientalis cells cultured in milk indicates an important role of $A$. orientalis in LacA production in Caucasian yogurt (Figure 6). However, in addition to $A$. orientalis, L. lactis ssp. cremoris is involved in the fermentation of yogurt prepared from the seed powder from Fujicco. The yogurts fermented by $L$. lactis ssp. cremoris alone are distributed as Caspian Sea yogurt in Japan, and we prepared fermented milks to use these yogurts as starter cultures. However, we failed to find LacA in these yogurts. On the other hand, LacA

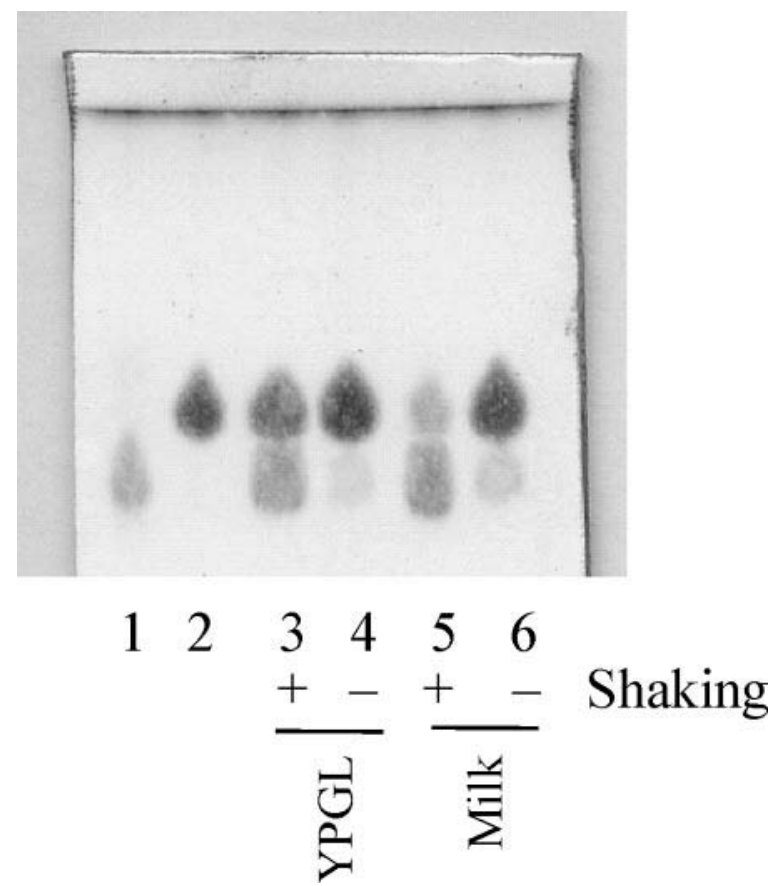

Figure 6. Lactobionic acid (LacA) production by resting cells cultured in yeast extract-polypepton-glucose-lactose (YPGL) liquid medium and milk. Acetobacter orientalis was cultured in $2.0 \mathrm{~mL}$ of YPGL liquid medium (lane 3,4) and milk (lane 5,6) at $27^{\circ} \mathrm{C}$ for $2 \mathrm{~d}$ with (lane 4,6) and without (lane 5, 7) shaking. After washing, the cells were reacted with $2 \%$ lactose and $0.026 \mathrm{~g} / \mathrm{mL}$ of $\mathrm{CaCO}_{3}$ at $27^{\circ} \mathrm{C}$ with shaking (240 oscillation/min). After $7 \mathrm{~h}$ of shaking, the reaction mixture was analyzed by thin-layer chromatography. Lanes 1 and 2 are the LacA and lactose standard, respectively.

was produced by adding a small amount of $A$. orientalis cultured broth $(10 \mu \mathrm{L})$ to these starter cultures (data not shown). Furthermore, contamination by unwanted bacteria did not significantly affect LacA production in the yogurt, because the $\mathrm{pH}$ of the yogurt became acidic for a few hours (Figure 4). In other experiments, the $\mathrm{pH}$ shifted rapidly to the acidic range. The conclusion that LacA in the Caucasian yogurt was produced by $A$. orientalis can be drawn from these results.

The LacA content of the yogurt suggested that the daily and annual intakes of LacA would be 1.0 to 3.0 $\mathrm{mg}$ and 0.5 to $1.0 \mathrm{~g}$, respectively, if $100 \mathrm{~g}$ of yogurt prepared with a commercial yogurt maker were eaten every day (Figure 5). Because Caucasian yogurt is customarily eaten at every meal during the day in the Caucasus region, the people living in this region would likely have a much larger intake of LacA than Japanese people over a long period.

As shown in Figure 6, A. orientalis cells produced less LacA in static culture than in shaking culture because of the difference in oxygen supply. This result supports the results shown in Figure 3. Lactobionic acid was more abundant in the upper layer (aerobic conditions) of the 


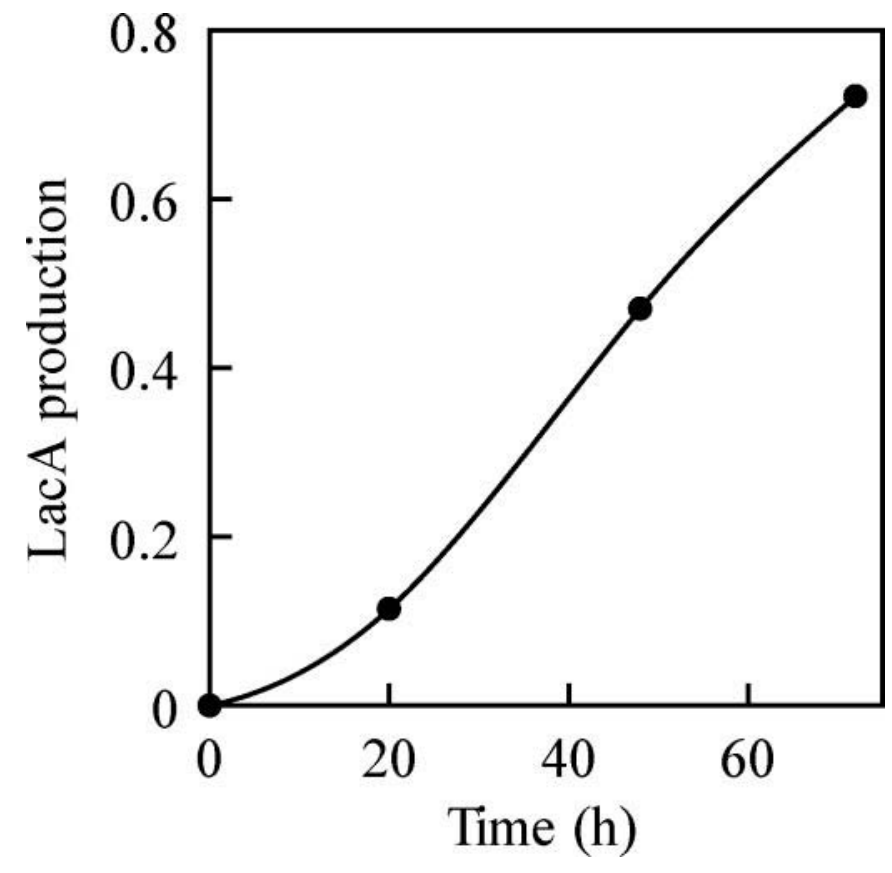

Figure 7. Time course of lactobionic acid (LacA) production in washed Acetobacter orientalis cells. Acetobacter orientalis was cultured in yeast extract-polypepton-glucose-lactose liquid medium at $27^{\circ} \mathrm{C}$ for $2 \mathrm{~d}$. The washed A. orientalis cells collected from $10 \mathrm{~mL}$ of culture broth were shaken (240 oscillations/min) with $2 \%$ lactose at $27^{\circ} \mathrm{C}$. Calcium carbonate ( $1 / 2$ equimolar amount of lactose) was added for neutralization. The concentration of LacA was measured by high-performance anion-exchange chromatography with pulsed amperometric detection.

yogurt than in the lower layers (anaerobic conditions), because the population of the aerobic bacteria would be larger at the surface. Furthermore, lactose oxidation is probably an aerobic process. The LacA content in the yogurt gradually increased during the fermentation period (Figure 4), because the $\mathrm{pH}$ of the yogurt and the optimal $\mathrm{pH}$ of the lactose-oxidizing activity were nearly the same (pH 4.0 to 4.5 ). Furthermore, A. orientalis did not grow on a mineral salt medium containing LacA, but did grow on a medium containing D-glucose. These results indicate that LacA was not utilized as a carbon source by A. orientalis. Kontula et al. (1999) reported that Lactococcus lactis ssp. lactis does not utilize LacA. Neither A. orientalis nor L. lactis ssp. cremoris, another microbe in the Caucasian yogurt, appeared to utilize LacA. Lack of assimilation of LacA by $A$. orientalis as well as by L. lactis are also reasons for the accumulation of LacA in the fermented milk product.

D-Glucose was the preferred substrate for the membrane-bound enzyme of $A$. orientalis (Figure 8). The specificity of this substrate was similar to that of a pyrrolo-quinoline quinone-dependent glucose dehydrogenase (GDH; EC 1.1.99.17; Cleton-Jansen et al., 1989a,b). Glucose dehydrogenase has been classified into
2 groups: soluble GDH (Dokter et al., 1986; Southall et al., 2006) and membrane-bound GDH (Matsushita et al., 1980, 1989; Ameyama et al., 1986). Soluble GDH has wide substrate specificity and oxidizes lactose at a considerable rate. In contrast, membrane-bound GDH specifically oxidizes monosaccharides and has no or extremely low activity against lactose. The oxidation activity of $A$. orientalis on lactose was located in the membrane fraction, and it oxidized D-glucose and some monosaccharides (Figure 8). The activities on lactose, maltose, and cellobiose were extremely low. The substrate specificity and the location of the sugar-oxidizing activity were similar to those of membrane-bound GDH. In contrast, GDH from other acetic bacteria, Acetobacter suboxydans (King and Cheldelin, 1956) and Gluconobacter oxydans (Matsushita et al., 1981), have been reported to show no activity on lactose. It was therefore difficult to conclude whether the enzyme in this study was membrane-bound GDH or a different type of enzyme. Further investigation is necessary to characterize the lactose-oxidizing enzyme.

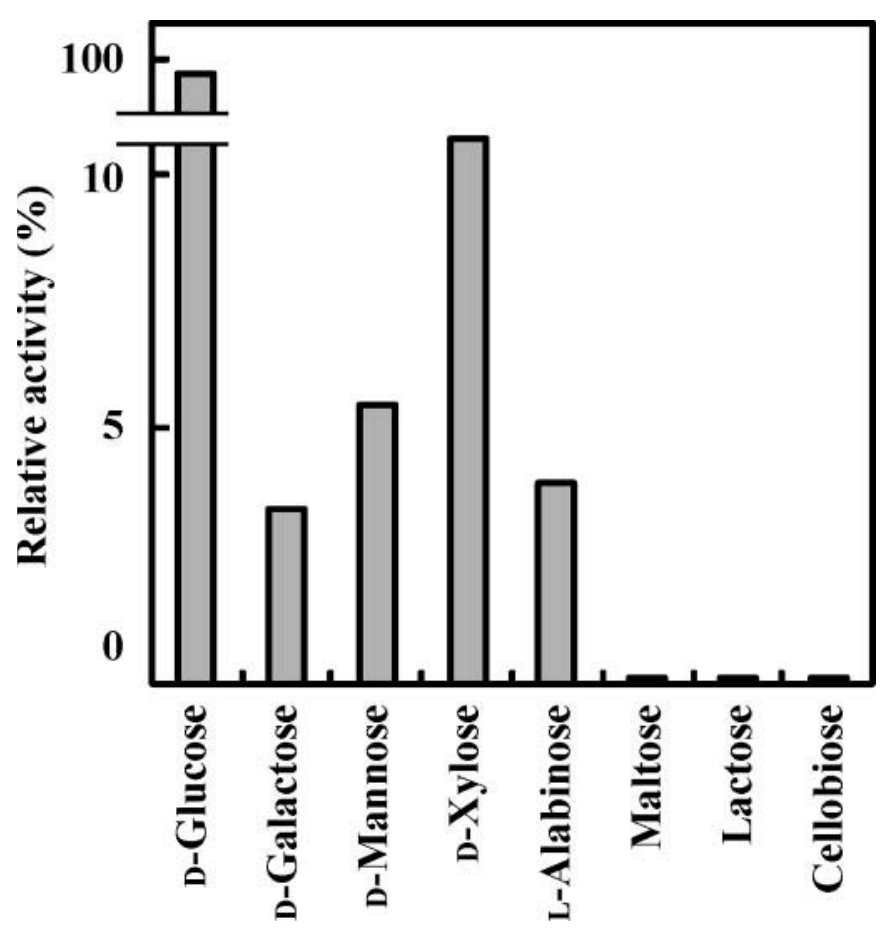

Figure 8. Substrate specificities of Acetobacter orientalis cells. Acetobacter orientalis was cultured in yeast extract-polypepton-glucose-lactose liquid medium at $27^{\circ} \mathrm{C}$ for $2 \mathrm{~d}$. Collected and washed cells were mixed with each sugar $(10 \mathrm{mM})$ and incubated at $27^{\circ} \mathrm{C}$ for $4 \mathrm{~h}$ with shaking (240 oscillations/min). The reaction mixtures were analyzed by high-performance anion-exchange chromatography with pulsed amperometric detection. The amount of each aldonic acid from the respective substrates was calculated by using LacA (disaccharide) and D-gluconic acid (monosaccharide) as standards. 
As shown in Figure 7, A. orientalis cells oxidized lactose to produce LacA. The conversion rate was slower during the first $24 \mathrm{~h}$ than that after $24 \mathrm{~h}$. The optimal $\mathrm{pH}$ of the oxidation activity of the cells was 4.5 , and the initial $\mathrm{pH}$ of the reaction mixture (approximately 7.6) was not suitable for the reaction. After $24 \mathrm{~h}$, the production of LacA changed the $\mathrm{pH}$ to a more suitable $\mathrm{pH}$ (approximately 6.8). The reaction mixture contained $0.72 \%(720 \mathrm{mg} / 100 \mathrm{~mL})$ of LacA after 72 $\mathrm{h}$ of incubation. This concentration was much greater than that shown in Figure $4(45 \mathrm{mg} / 100 \mathrm{~g}$ of upper layer of yogurt) and Figure 5 (1.4 to $2.8 \mathrm{mg} / 100 \mathrm{~g}$ of yogurt). The primary cause of these differences is that the reaction mixture $(1.0 \mathrm{~mL})$ shown in Figure 7 contained a large amount of cells collected from $10 \mathrm{~mL}$ of the cultured broth. These differences also indicate the importance of oxygen supply both in the culture and in the reaction, because the experiment shown in Figure 7 involved shaking during both the culture and reaction, and the yogurt was prepared by static fermentation.

Several lactose-oxidizing enzymes from fungi, such as carbohydrate:acceptor oxidoreductase (Xu et al., 2001; Hua et al., 2007; Kiryu et al., 2008), glucooligosaccharide oxidase (Lin et al., 1991; Lee et al., 2005), and cellobiose dehydrogenase (EC 1.1.99.18; Ludwig et al., 2004), have been studied for their ability to produce LacA. Furthermore, bacteria (Nishizuka and Hayaishi, 1962; Satory et al., 1997; Murakami et al., 2006), algae (Bean and Hassid, 1956; Sullivan and Ikawa, 1973), and citrus fruits (Bean et al., 1961) with lactose-oxidizing activities have been studied for LacA production. Most of the lactose-oxidizing organisms investigated, however, were not appropriate for the production of LacA for food. On the other hand, Acetobacter has been used in food production, such as in the production of vinegar, for a long time and safe production processes are well established. If a strain with high lactose-oxidizing activity is established or if the conditions necessary for high oxidizing activity are determined, this bacterium could be used for the production of edible LacA.

\section{REFERENCES}

Akatani, K., and T. Ishida. 2002. Symbiosis of lactic acid bacteria and aerobic bacteria in ropy fermented milk of Georgian origin. Jpn. Lactic Acid Bacteria 13:63 (in Japanese).

Ameyama, M., M. Nonobe, E. Shinagawa, K. Matsushita, K. Takimoto, and O. Adachi. 1986. Purification and characterization of the quinoprotein D-glucose dehydrogenase apoenzyme from Escherichia coli. Agric. Biol. Chem. 50:49-57.

Bean, R. C., and W. Z. Hassid. 1956. Carbohydrate oxidase from a red alga, Iridophycus flaccidum. J. Biol. Chem. 218:425-436.

Bean, R. C., G. G. Porter, and B. M. Steinberg. 1961. Carbohydrate metabolism of citrus fruits. J. Biol. Chem. 236:1235-1240.

Brommage, R., C. Binacua, S. Antille, and A. L. Carrie. 1993. Intestinal calcium absorption in rats is stimulated by dietary lactulose and other resistant sugars. J. Nutr. 123:2186-2194.
Cleton-Jansen, A. M., N. Goosen, K. Vink, and P. van de Putte. 1989a. Cloning, characterization and DNA sequencing of the gene encoding the Mr 50,000 quinoprotein glucose dehydrogenase from Acinetobacter calcoaceticus. Mol. Gen. Genet. 217:430-436.

Cleton-Jansen, A. M., N. Goosen, K. Vink, and P. van de Putte. 1989b. Cloning of the genes encoding the two different glucose dehydrogenases from Acinetobacter calcoaceticus. Antonie Van Leeuwenhoek 56:73-79.

Dokter, P., J. Frank, and J. A. Duine. 1986. Purification and characterization of quinoprotein glucose dehydrogenase from Acinetobacter calcoaceticus L.M.D. 79.41. Biochem. J. 239:163167

Hua, L., M. Nordkvist, P. M. Nielsen, and J. Villadsen. 2007. Scale-up enzymatic production of lactobionic acid using the rotary jet head system. Biotechnol. Bioeng. 97:842-849.

Ishida, T., A. Yokota, Y. Umezawa, T. Toda, and K. Yamada. 2005. Identification and characterization of lactococcal and Acetobacter strains isolated from traditional Caucasian fermented milk. J. Nutr. Sci. Vitaminol. (Tokyo) 51:187-193.

King, T. E., and V. H. Cheldelin. 1956. Glucose oxidation and cytochromes in solubilized particulate fractions of Acetobacter suboxydans. J. Biol. Chem. 224:579-590.

Kiryu, T., H. Nakano, T. Kiso, and H. Murakami. 2008. Purification and characterization of a carbohydrate:acceptor oxidoreductase from Paraconiothyrium sp. that produces lactobionic acid efficiently. Biosci. Biotechnol. Biochem. 72:833-841.

Kontula, P., M.-L. Suihko, A. von Wright, and T. Mattila-Sandholm. 1999. The effect of lactose derivatives on intestinal lactic acid bacteria. J. Daily Sci. 82:249-256.

Lee, M. H., W. L. Lai, S. F. Lin, C. S. Hsu, S. H. Liaw, and Y. C. Tsai. 2005. Structural characterization of glucooligosaccharide oxidase from Acremonium strictum. Appl. Environ. Microbiol. 71:88818887.

Lin, S. F., T. Y. Yang, T. Inukai, M. Yamasaki, and Y. C. Tsai. 1991. Purification and characterization of a novel glucooligosaccharide oxidase from Acremonium strictum T1. Biochim. Biophys. Acta 118:41-47.

Ludwig, R., M. Ozga, M. Zamocky, C. Peterbauer, K. D. Kulbe, and D. Haltrich. 2004. Continuous enzymatic regeneration of electron acceptor used by flavoenzymes: Cellobiose dehydrogenase-catalyzed production of lactobionic acid as an example. Biocat. Biotrans. 22:97-104.

Matsushita, K., Y. Ohno, E. Shinagawa, O. Adachi, and M. Ameyama. 1980. Membrane-bound D-glucose dehydrogenase from Pseudomonas sp.: Solubilization, purification and characterization. Agric. Biol. Chem. 44:1505-1512.

Matsushita, K., Y. Ono, E. Shinagawa, O. Adachi, and M. Ameyama. 1981. D-Glucose dehydrogenase of Gluconobacter suboxydans: Solubilization, purification and characterization. Agric. Biol. Chem. 45:851-861.

Matsushita, K., E. Shinagawa, O. Adachi, and M. Ameyama. 1989. Quinoprotein D-glucose dehydrogenases in Acinetobacter calcoaceticus LMD 79.41: Purification and characterization of the membrane-bound enzyme distinct from the soluble enzyme. Antonie Van Leeuwenhoek 56:63-72.

Murakami, H., J. Kawano, H. Yoshizumi, H. Nakano, and S. Kitahata. 2002. Screening of lactobionic acid producing microorganisms. J. Appl. Glycosci. 49:469-477.

Murakami, H., A. Seko, M. Azumi, T. Kiso, T. Kiryu, S. Kitahata, Y. Shimada, and H. Nakano. 2006. Microbial conversion of lactose to lactobionic acid by resting cells of Burkholderia cepacia no. 24. J. Appl. Glycosci. 53:7-11.

Nakano, H., T. Kiryu, T. Kiso, and H. Murakami. 2006. Lactobionic acid and its biocatalytic production. Foods Food Ingred. J. Jpn. 211:874-881. (in Japanese)

Neaverson, M. A. 1976. Intravenous administration of erythromycin: Serum, sputum and urine levels. Curr. Med. Res. Opin. 4:359 364

Nishizuka, Y., and O. Hayaishi. 1962. Enzymic formation of lactobionic acid from lactose. J. Biol. Chem. 237:2721-2728. 
Satory, M., M. Furlinger, D. Haltrich, K. D. Kulbe, F. Pittner, and B. Nidetzky. 1997. Continuous enzymatic production of lactobionic acid using glucose-fructose oxidoreductase in ultrafiltration membrane reactor. Biotechnol. Lett. 19:1205-1208.

Southall, S. M., J. J. Doel, D. J. Richardson, and A. Oubrie. 2006. Soluble aldose sugar dehydrogenase from Escherichia coli: A highly exposed active site conferring broad substrate specificity. J. Biol. Chem. 281:30650-30659.

Sullivan, J. D., and M. Ikawa. 1973. Purification and characterization of hexose oxidase from the red alga Chondrus crispus. Biochim. Biophys. Acta 309:11-22.
Sumimoto, R., K. Dohi, T. Urushihara, N. V. Jamieson, H. Ito, K. Sumimoto, and Y. Fukuda. 1992. An examination of the effects of solutions containing histidine and lactobionate for heart, pancreas, and liver preservation in the rat. Transplantation 53:1206-1210.

Wahlberg, J. A., R. Love, L. Landegaard, J. H. Southard, and F. O. Belzer. 1987. 72-Hour preservation of the canine pancreas. Transplantation $43: 5-8$.

Xu, F., E. J. Golightly, C. C. Fuglsang, P. Schneider, K. R. Duke, L. Lam, S. Christensen, K. M. Brown, C. T. Jorgensen, and S. H. Brown. 2001. A novel carbohydrate:acceptor oxidoreductase from Microdochium nivale. Eur. J. Biochem. 268:1136-1142. 